DiRECTEUR DE LA PUBlication: Bruno David

Président du Muséum national d'Histoire naturelle

RÉDACTRICE EN CHEF / EDITOR-IN-CHIEF : Laure Desutter-Grandcolas

AssistanTS DE RÉDACTION / AsSISTANT EDITORS: Anne Mabille (zoosyst@mnhn.fr), Emmanuel Côtez

Mise en PAge / PAgE LAYOUt: Anne Mabille

COMITÉ SCIENTIFIQUE / SCIENTIFIC BOARD:

James Carpenter (AMNH, New York, États-Unis)

Maria Marta Cigliano (Museo de La Plata, La Plata, Argentine)

Henrik Enghoff (NHMD, Copenhague, Danemark)

Rafael Marquez (CSIC, Madrid, Espagne)

Peter Ng (University of Singapore)

Gustav Peters (ZFMK, Bonn, Allemagne)

Norman I. Platnick (AMNH, New York, États-Unis)

Jean-Yves Rasplus (INRA, Montferrier-sur-Lez, France)

Jean-François Silvain (IRD, Gif-sur-Yvette, France)

Wanda M. Weiner (Polish Academy of Sciences, Cracovie, Pologne)

John Wenzel (The Ohio State University, Columbus, États-Unis)

COUVERTURE / COVER:

Monchenkocyclops mehmetadami Karaytuğ, Bozkurt \& Sönmez, 2018, holotype .

\author{
Zoosystema est indexé dans / Zoosystema is indexed in: \\ - Science Citation Index Expanded (SciSearch ${ }^{\circledR}$ ) \\ - ISI Alerting Services ${ }^{\circledR}$ \\ - Current Contents ${ }^{\circledR}$ / Agriculture, Biology, and Environmental Sciences ${ }^{\circledR}$ \\ - Scopus ${ }^{\circledR}$
}

Zoosystema est distribué en version électronique par / Zoosystema is distributed electronically by:

- BioOne ${ }^{\circledR}$ (http://www.bioone.org)

Les articles ainsi que les nouveautés nomenclaturales publiés dans Zoosystema sont référencés par / Articles and nomenclatural novelties published in Zoosystema are referenced by:

- ZooBank ${ }^{\circledR}$ (http://zoobank.org)

Zoosystema est une revue en flux continu publiée par les Publications scientifiques du Muséum, Paris / Zoosystema is a fast track journal published by the Museum Science Press, Paris

Les Publications scientifiques du Muséum publient aussi / The Museum Science Press also publish:

Adansonia, Anthropozoologica, European Journal of Taxonomy, Geodiversitas, Naturae.

Diffusion - Publications scientifiques Muséum national d'Histoire naturelle

CP 41 - 57 rue Cuvier F-75231 Paris cedex 05 (France)

Tél. : 33 (0)1 40794805 / Fax: 33 (0)1 40793840

diff.pub@mnhn.fr / http://sciencepress.mnhn.fr

(C) Publications scientifiques du Muséum national d'Histoire naturelle, Paris, 2018

ISSN (imprimé / print): 1280-9551/ ISSN (électronique / electronic): 1638-9387

PHOTOCOPIES :

Les Publications scientifiques du Muséum adhèrent au Centre Français d'Exploitation du Droit de Copie (CFC), 20 rue des Grands Augustins, 75006

Paris. Le CFC est membre de l'International Federation of Reproduction Rights Organisations (IFRRO). Aux États-Unis d'Amérique, contacter le Copyright Clearance Center, 27 Congress Street, Salem, Massachusetts 01970.
PHOTOCOPIES:

The Publications scientifiques du Muséum adhere to the Centre Français d'Exploitation du Droit de Copie (CFC), 20 rue des Grands Augustins, 75006 Paris. The CFC is a member of International Federation of Reproduction Rights Organisations (IFRRO). In USA, contact the Copyright Clearance Center, 27 Congress Street, Salem, Massachusetts 01970. 


\title{
A new hyporheic Monchenkocyclops Karanovic, Yoo \& Lee, 2012 (Crustacea: Copepoda) from Turkey with special emphasis on antennulary homology
}

\author{
Süphan KARAYTUĞ \\ Faculty of Art and Sciences, Department of Biology, \\ Mersin University, 33343, Mersin (Turkey) \\ suphankaraytug@gmail.com
}

Ahmet BOZKURT

Faculty of Marine Sciences and Technology, Iskenderun Technical University, 31200, Iskenderun, Hatay (Turkey)

Serdar SÖNMEZ

Faculty of Art and Sciences, Department of Biology, 02040, Adıyaman University, Adıyaman (Turkey)

Submitted on 20 February 2017 | Accepted on 12 June 2017 | Published on 30 January 2018

KEY WORDS

Homology,

Cyclopoida,

phylogeny,

fauna,

new species.

MOTS CLÉS

Homologie,

Cyclopoida,

phylogénie,

espèce nouvelle.
urn:Isid:zoobank.org:pub:155D423A-9252-4B32-9471-B5CA7F36FED4

Karaytuğ S., Bozkurt A. \& Sönmez S. 2018. - A new hyporheic Monchenkocyclops Karanovic, Yoo \& Lee, 2012 (Crustacea: Copepoda) from Turkey with special emphasis on antennulary homology. Zoosystema 40 (2): 43-58. https://doi. org/10.5252/zoosystema2018v40a2. http://zoosystema.com/40/2

\section{ABSTRACT}

Both sexes of Monchenkocyclops mehmetadami n. sp. were described from hyporheic freshwater habitat in Turkey. The new species can easily be distinguished from the other four species in the genus by having three setae on the inner margin of the second endopodal segment of the first and second swimming legs and four setae on the inner margin of second endopodal segment of the third and fourth swimming legs. The setation patterns of female and male antennules of the new species are analyzed with reference to the hypothetical 28- segmented antennule of ancestral copepod and the homology of the antennulary segments is determined in both sexes. Paraphyletic status of the genus is briefly discussed.

\section{RÉSUMÉ}

Un nouveau Monchenkocyclops Karanovic, Yoo \& Lee, 2012 hyporhéique de Turquie (Crustacea: Copepoda), avec l'étude des homologies sur les antennules.

Mâles et femelles de Monchenkocyclops mehmetadami n. sp. sont décrits d'un habitat d'eau douce hyporhéique en Turquie. La nouvelle espèce peut facilement être distinguée des quatre autres espèces du genre par ses trois soies sur le bord interne du deuxième segment endopodal des premières et secondes pattes natatoires, et ses quatre soies sur le bord interne du deuxième segment endopodal des troisièmes et quatrièmes pattes natatoires. Les patrons de distribution des soies sur les antennules des femelles et des mâles de la nouvelle espèce sont analysés en référence au plan de base hypothétique de l'antennule chez les copépodes, avec 28 segments, et les homologies des segments antennulaires sont déterminées chez les deux sexes. Le statut paraphylétique du genre est brièvement discuté. 


\section{INTRODUCTION}

Understanding the taxonomy and phylogenetic relationships between the genera of family Cyclopidae Rafinesque, 1815 is still a challenge. One of the main problems is the presence of many species (Boxshall \& Halsey 2004) that are arbitrarily included in some genera. This makes a comprehensive revision more problematic. Creating some new genera based on well defined generic characters is a sensible and most desirable way of reducing this heavy job. But, the recent creation of the genus Monchenkocyclops Karanovic, Yoo \& Lee, 2012 is also an alternative and acceptable example of such action despite the fact that the genus is clearly paraphyletic (Karanovic et al. 2012) and seems to stand basal to the kieferi-group of Acanthocyclops Kiefer, 1927 (Pandourski 1997; Iepure \& Defaye 2008) as well as to some members of some other genera (Karanovic et al. 2012).

Monchenkocyclops was created to include four morphologically very closely related species of Acanthocyclops. The members of the genus can only be distinguished from each other mostly by the minor differences such as the relative lengths of different armature elements (Karanovic et al. 2012). During the extensive sampling of the freshwater copepods of Turkish inland waters a new species cyclopoid copepod was collected. The new species morphologically very similar to the members the genus Monchenkocyclops in terms of the same segmentation of the swimming legs, absence of exopod on the antenna, fifth leg, the caudal rami shape and armature, similar spinular ornamentation of the appendages, etc. Both sexes of the new species are described in detail below.

\section{MATERIAL AND METHODS}

Specimens were collected from insterstitial/hyporheic habitat of the Kırksu creek, southwestern Turkey by the KaramanChappuis method (Delamare Deboutteville 1953) and were fixed in $4 \%$ buffered formalin. Locality data and number of specimens are given in the type material/locality sections of the new species below, and type materials are deposited in the Zoology Museum of Adryaman University (ZMADYU) and in the Muséum national d'Histoire naturelle (MNHN), Paris. Specimens were dissected in lactic acid and the dissected parts were mounted in lactophenol. Broken glass fibres were added to prevent the animal and appendages from being compressed by the coverslip and to facilitate rotation and manipulation, allowing observation from all angles. Preparations were subsequently sealed with Entellan ${ }^{\oplus}$ (Merck). All drawings were prepared using a drawing tube on an Olympus BX-51 differential interference contrast microscope. Total body length was measured from the frontal margin of the dorsal cephalothoracic shield to the posterior margin of the caudal rami. Measurements were made with an ocular micrometer. Scale bars in illustrations are in $\mu \mathrm{m}$. Body width is given as the widest part of the cephalothorax. In the spine and seta formula of the swimming legs Roman numerals and Arabic numerals are used for spines and setae, respectively. The descriptive terminology used by Huys \& Boxshall (1991) is adopted. The terms "frontal" and "caudal" introduced by Van de Velde (1984) to denote the anterior and posterior surface of the antennary coxobasis are also adopted here. Terminology for the caudal ramus setae is adopted from Huys et al. (1996) and the numbering system for the homologous structures on the first segment of male antennule is adopted from Karaytuğ \& Boxshall (1999).

Scanning electron microscopy (SEM) examinations were made on a Zeiss SUPRA 55VP (FESEM) microscope in Mersin University Advanced Technology Education, Research and Application Centre (MEITAM). Specimens for SEM observation were prepared as described in Kaymak \& Karaytuğ (2014).

\section{ABBREVIATIONS \\ ae aesthetasc; \\ exp(enp)-1 $(2,3)$ the proximal (middle, distal) segment of a three- P1-P6 legs 1-6.}

\section{SYSTEMATICS}

Order CYCLOPOIDA Rafinesque, 1815

Family CyClOPIDAE Rafinesque, 1815

Subfamily CYClOPINAE Rafinesque, 1815

Genus Monchenkocyclops Karanovic, Yoo \& Lee, 2012

Monchenkocyclops mehmetadami n. sp. (Figs 1-10)

TyPe lOCAlity. - Kirksu Creek, Kozan, Adana, Turkey. Coordinates $37^{\circ} 32^{\prime} 08.46^{\prime \prime} \mathrm{N}, 35^{\circ} 53^{\prime} 41.54$ 'E.

Type Material. - Holotype $\$$ dissected on eight slides (ZMADYU2015/135). Allotype $0^{\prime \prime}$ also dissected on eight slides (ZMADYU2015/136). 1 paratype $\sigma^{7}$ and 1 paratype $o$ are dissected on one slide each; $2 \sigma^{\circ}$ and 19 preserved in alcohol (ZMADYU2015/137); $1 \sigma^{7}$ and 19 on one SEM stub (ZMADYU2015/138). $20^{7}$ and 2 \% preserved in alcohol (MNHN). Date 13.VI.2015. Leg. Ahmet Bozkurt.

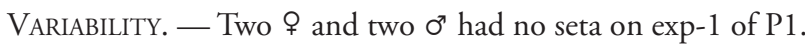

Etymology. - The new species is named in honor of Prof. Dr Mehmet Adam (Başkent University, Turkey).

\section{DESCRIPTION OF FEMALE (HOLOTYPE) \\ Total body length}

Excluding caudal setae, $667 \mu \mathrm{m}$ (range: 618-779 $\mu \mathrm{m}$, mean $=668 \mu \mathrm{m}, n=6)$; body width $242 \mu \mathrm{m}($ range $=239-294 \mu \mathrm{m}$, mean $=257 \mu \mathrm{m}, n=6$ ). Preserved specimens colorless; no live specimens observed. Pedigerous somite smooth along posterior margin (Fig. 1A). Urosomites (Figs 2B; 6A, B) with fine hyaline frills along the posterior margin on ventral and dorsal surfaces. Integumental pore/sensilla pattern of the prosomites extremely difficult to observe/confirm, but in general similar to that of $M$. changi Karanovic, Yoo \& Lee, 2012 (Fig. 1A). Seminal receptacle with relatively 


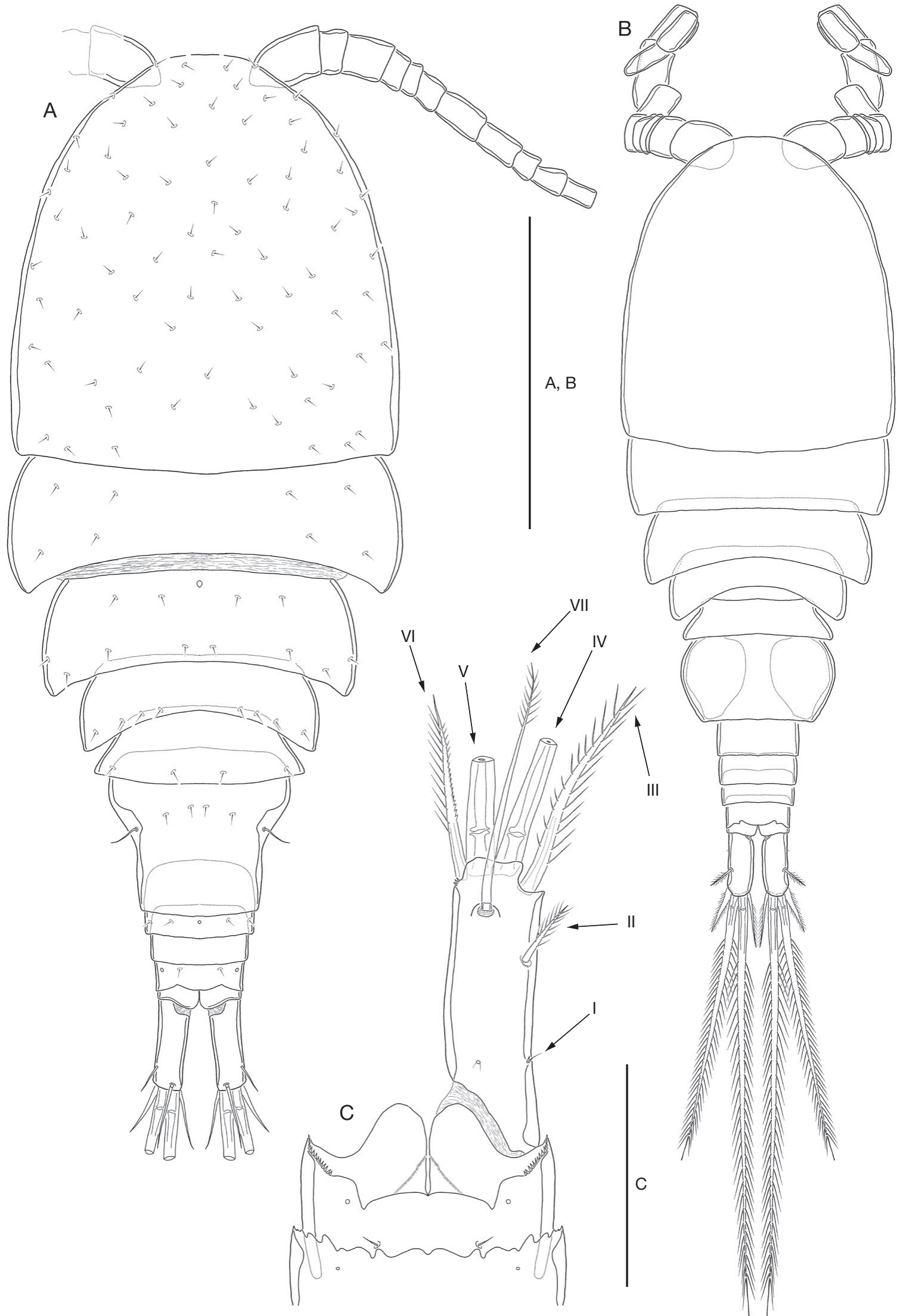

FIG. 1. - Monchenkocyclops mehmetadami n. sp.: A, holotype $\odot$, habitus, dorsal view; B, allotype ơ, habitus, dorsal view; C, holotype ${ }^{\gamma}$, anal somite and furca, dorsal view, setae are indicated by Roman numerals, following Huys et al. (1996). Not all integumental pore and sensilla of the prosomites are drawn as they are extremely difficult to observe even under $100 \times$ magnification, but in general similar to that of $M$. changi Karanovic, Yoo \& Lee, 2012 . Scale bars: $50 \mu$ m. 


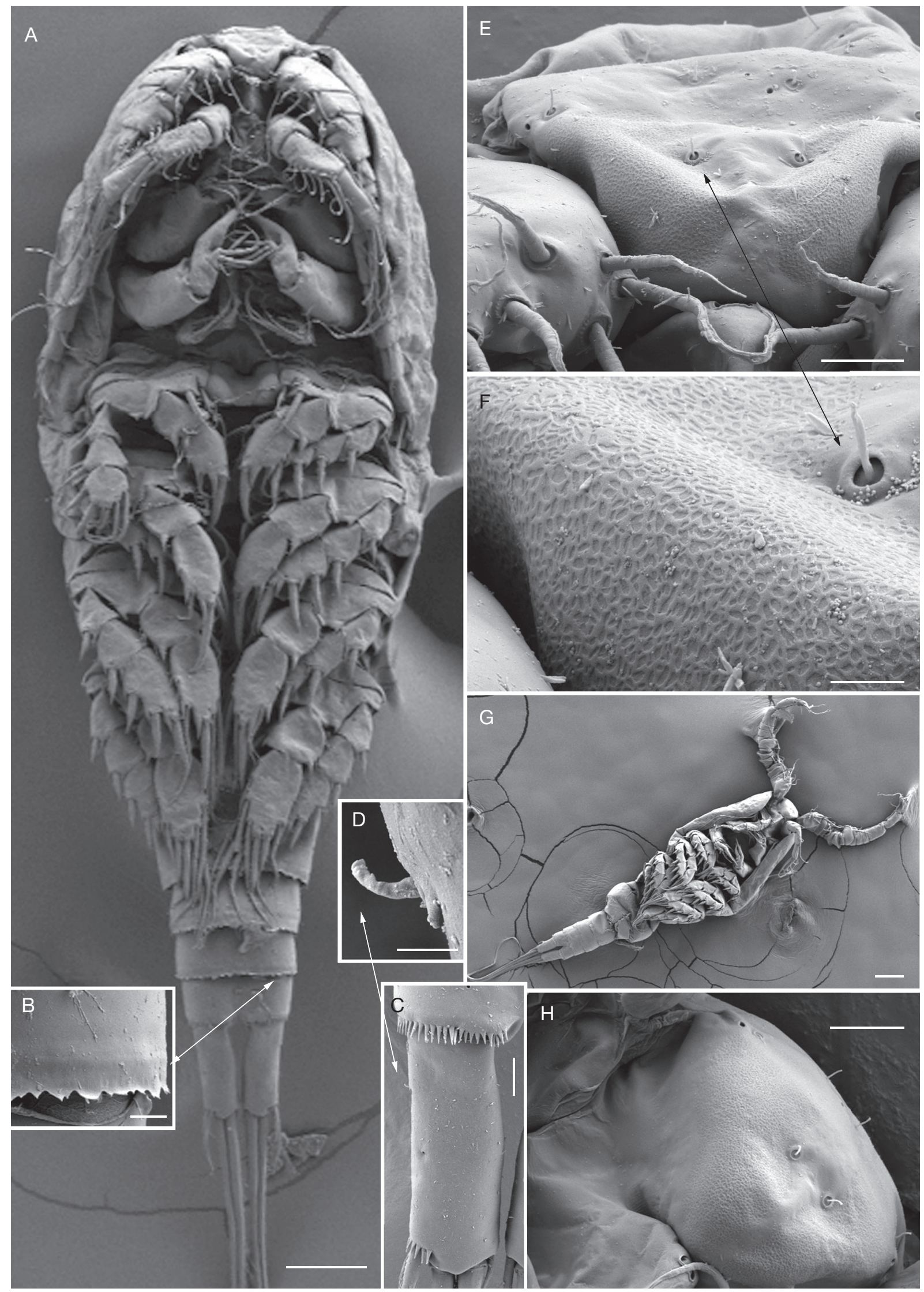

FIG. 2. - Scanning electron micrographs of Monchenkocyclops mehmetadami n. sp.: A, paratype $\%$, habitus, ventral view; $\mathbf{B}$, inset showing hyaline frills on the third abdominal somite; C, details of caudal ramus, ventral view; D, inset showing seta I; E, F, rostrum, arrow indicating a sensilla; $\mathbf{G}$, paratype $0^{7}$, habitus, ventral view; H, paratype ơ , rostrum, anterior view. Scale bars: A, G, $20 \mu \mathrm{m} ; \mathrm{B}, 2 \mu \mathrm{m} ; \mathrm{C}, \mathrm{E}, \mathrm{H}, 4 \mu \mathrm{m} ; \mathrm{D}, \mathrm{F}, 1 \mu \mathrm{m}$. 

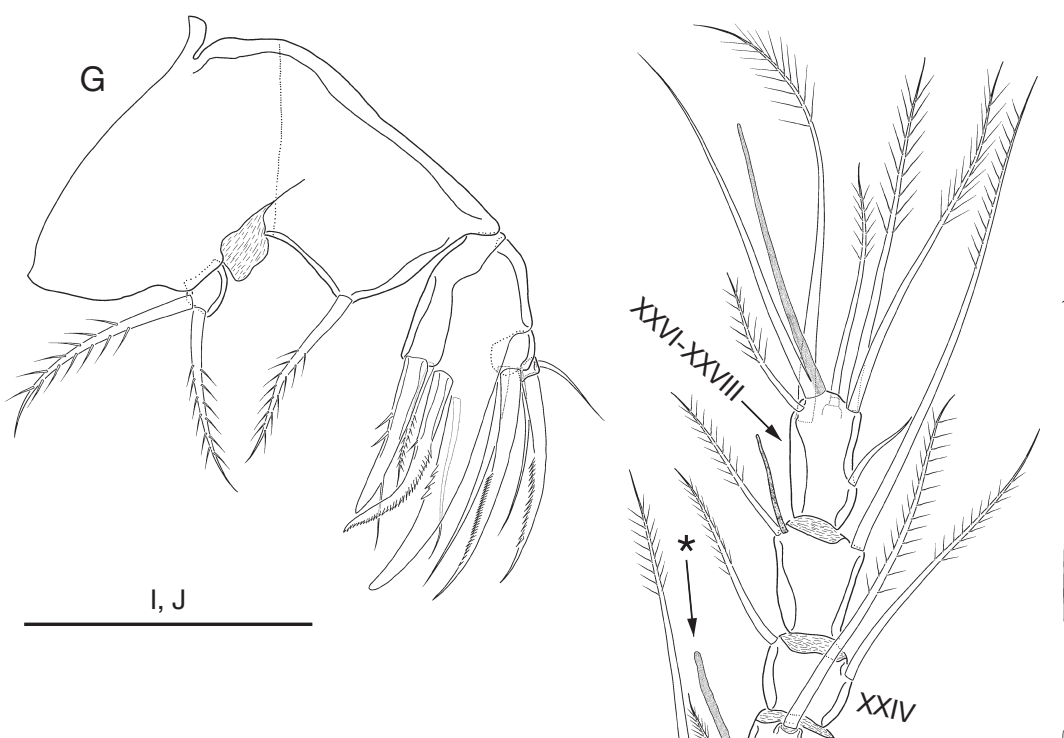

D f

$\mathrm{C}, \mathrm{H}$

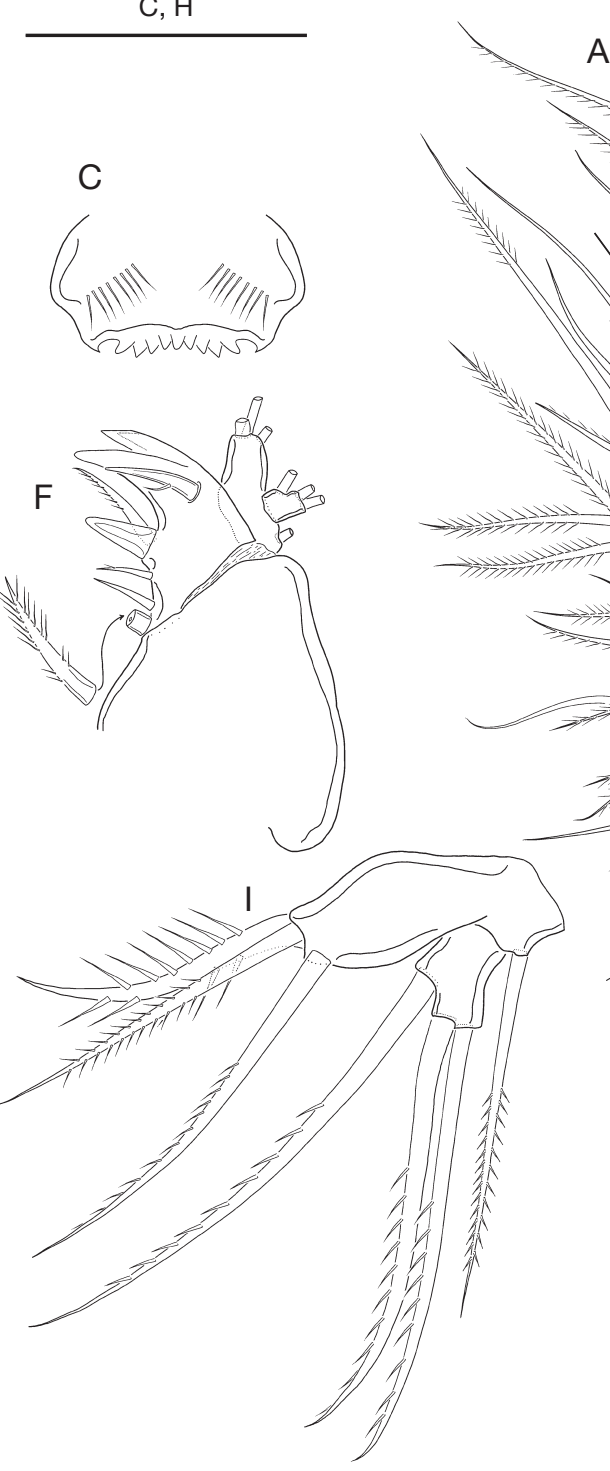

A
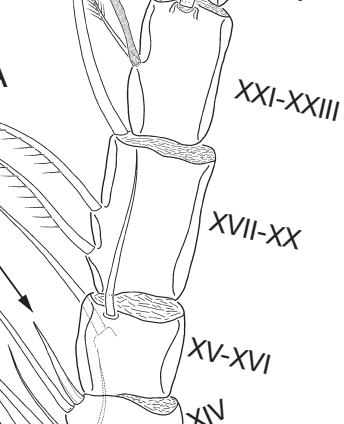

$x V I I-x x$

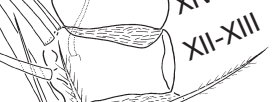

\section{(1)}
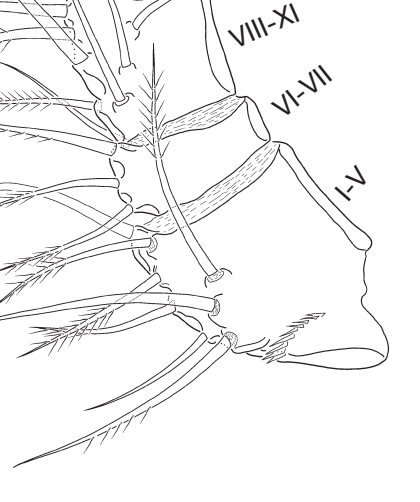

B

A, B

FIG. 3. - Monchenkocyclops mehmetadami n. sp., holotype $\%$ : A, antennule, ventral view, roman numerals indicating segment homologies as proposed by Huys \& Boxshall (1991); B, antenna, caudal view; C, labrum, anterior view; D, mandible, ventral view; E, mandible, anterior view; F, maxillule, posterior view; G, maxilla, anterior view; H, maxilliped, posterior view; I, maxillulary palp, anterior view; J, P5, ventral view. Scale bars: A-H, $50 \mu \mathrm{m} ; \mathrm{I-J}, 25 \mu \mathrm{m}$. 
large anterior expansion and smaller posterior expansion as figured (Fig. 6A)

Genital double-somite (Fig. 6A, B) large, with deep lateral recesses at level of sixth legs and swollen antero-ventrally, widest in anterior third and gradually tapering posteriorly, about 1.2 times as wide as long (dorsal view), hyaline fringe deeply and irregularly serrated. Copulatory pore very small, ovoid, situated ventrally at about midlength of double-somite ventrally; copulatory duct narrow, siphon-shaped, weakly sclerotized. Seminal receptacle (Fig. 6A) with relatively large anterior expansion and much smaller posterior expansion, extending over $49 \%$ of double-somite's length; oviducts broad and weakly sclerotized. Ovipores situated dorsolaterally at $2 / 5$ of double-somite length, covered by reduced sixth legs. Third and fourth urosomites similar in length and without ornamentation.

\section{Anal somite (Fig. 1C)}

With short medial cleft, ornamented with one pair of dorsal sensilla, two pairs of small dorsal pores, with distal spinular row ventrally, extending dorsally to either side of anal operculum. Anal sinus wide with minute transverse spinules. Anal operculum slightly convex.

\section{Caudal rami (Figs 1C; 2C)}

Cylindrical, parallel, inserted close to each other, about 3.8 times longer than broad (measured in dorsal view); armed with seven setae, armature consisting of seven setae: seta I with minute spinule (Figs 1C; 6A, B, D); setae II and III plumose; seta IV and V plumose with fracture plane, seta V longest; seta VI located at inner distal corner semispinulose, about as long as seta III; seta VII plumose and triarticulate at base.

Rostrum (Fig. 2A, E, H) not demarcated at base, ornamented with integumental pits (Fig. 2F) broadly rounded and furnished with single central sensilla frontally (arrowed in Fig. 2E, F). The difference observed between female and male rostrum (Fig. 2E, H) is due to wrinkling during the critical point drying procedure.

\section{Antennule eleven-segmented (Fig. 3A)}

With spinular row on the first segment proximoventrally. Segment 5 with spiniform seta (arrowed in Fig. 3A). Segment 8 with characteristic aesthetasc (arrowed in Fig. 3A). Setal formula 8, 4, 8, 4, 2, 2, 3, 2 + aesthetasc, 2, 2 + aesthetasc, $7+$ aesthetasc. Most setae sparsely pinnate or plumose as figured. One apical seta on eleventh segment fused basally to an aesthetasc.

\section{Antenna (Fig. 3B)}

Five-segmented, strongly curved along caudal margin, comprising very short coxa, much longer basis and threesegmented endopod. Coxa small and without armature or ornamentation. Basis cylindrical with spinular rows on caudal and frontal surfaces as figured, and armed with two inner pinnate setae (exopodal seta absent). First endopodal segment with inner distal naked seta and spinules along outer margin. Second endopodal segment with nine setae, one of which at inner distal corner more robust; ornamented with spinules along outer margin. Third endopodal segment armed with seven setae around apex; outer margin ornamented with spinules.

\section{Labrum (Fig. 3C)}

Ornamented with paired groups of long spinules on anterior surface. Free posterior margin almost straight, with sharp teeth in midsection between produced and sharply and inwardly pointed lateral corners.

\section{Mandible (Fig. 3D, E)}

Composed of coxa and small palp. Cutting edge of gnathobase with several apical teeth, and dorsalmost unipinnate seta. Palp represented by three naked setae, two of which long and one short (Fig. 4B).

\section{Maxillule (Fig. 3F)}

Composed of praecoxa and two-segmented palp. Praecoxal arthrite armed with four setae articulating at base (proximalmost one more robust, longest and plumose) and five spines (three of which fused to segment). Proximal segment of the palp (Fig. 3I) representing fused coxa and basis, bearing one strong spinulose seta and two pinnate setae apically, plus outer pinnate seta representing exopod. Distal segment of palp, representing endopod, armed with three unipinnate setae (Fig. 3I).

\section{Maxilla (Fig. 3G)}

Five-segmented comprising praecoxa, coxa, basis and two- segmented endopod. Praecoxa partly fused to coxa on anterior surface and arthrodial membrane indicating segmental boundary; praecoxal endite with two spinulose setae. Coxa with proximal endite represented by single plumose seta; distal endite cylindrical, with strong spinulose spine and plumose seta apically. Basis drawn out into powerful curved claw (Fig. 4A) bearing coarse spinules along middle part of inner margin; accessory armature consisting of strong spinulose curved spine and naked seta. First endopodal segment with one unipinnate and one naked seta, second segment with two naked and one unipinnate setae (Fig. 4A).

\section{Maxilliped (Figs 3H; 4C)}

Much smaller than maxilla and four-segmented comprising syncoxa, basis, and two-segmented endopod. Syncoxa armed with two spinulose setae representing endites. Basis armed with two long spinulose setae; ornamented with two transverse rows of spinules near outer margin posteriorly and patch of spinules anteriorly near inner margin. First endopodal segment with long spinulose seta. Second endopodal segment with three setae, two of which naked; other pinnate.

\section{Legs 1-4}

With three-segmented exopod and two-segmented endopod (Fig. 5A-E). 

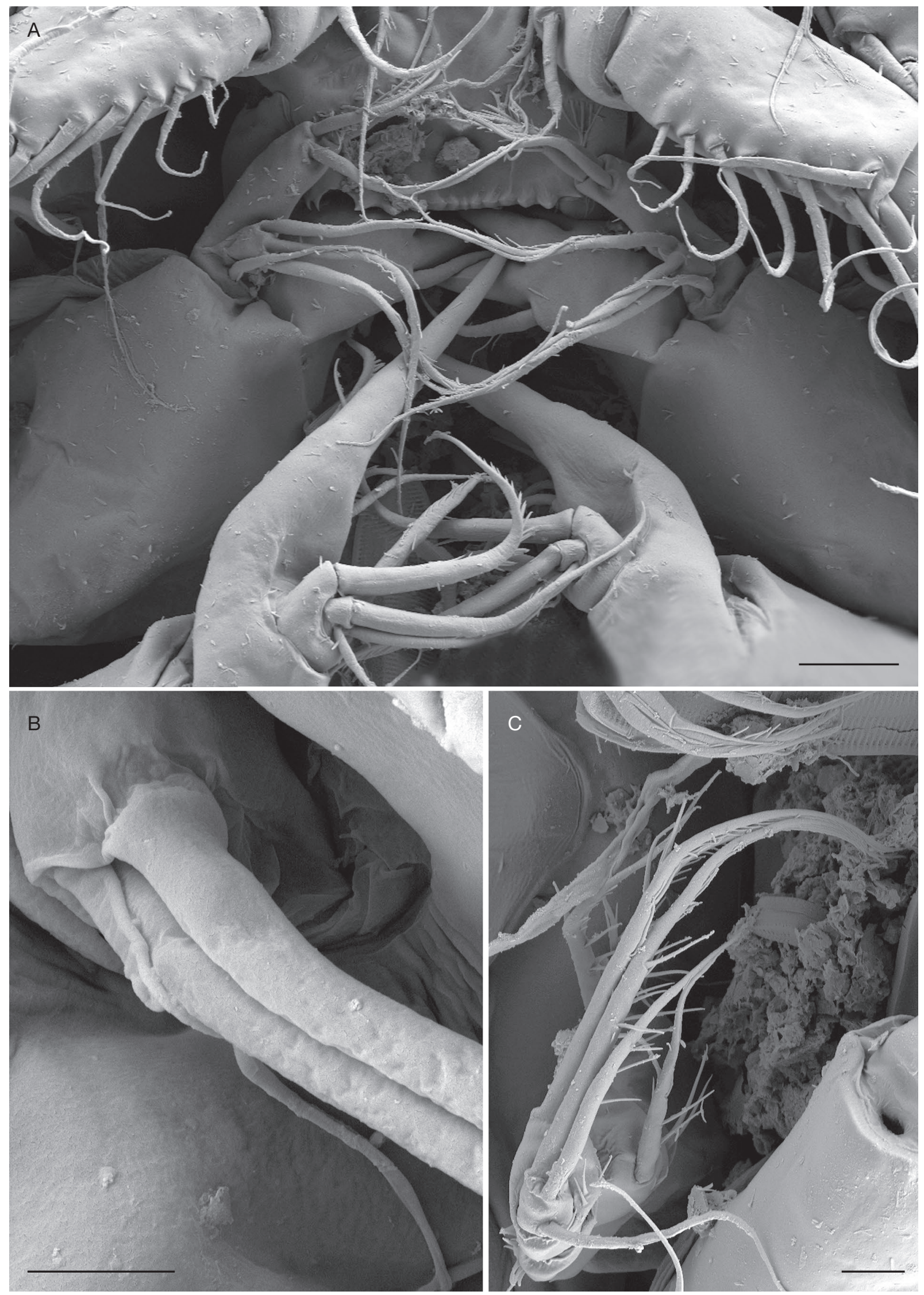

FlG. 4. - Scanning electron micrographs of Monchenkocyclops mehmetadami n. sp., paratype o: A, mouth region, ventral view; B, mandible, exopod, ventral view; C, anterior end of maxilliped, ventral view. Scale bars: A, $5 \mu \mathrm{m} ; \mathrm{B}, 1 \mu \mathrm{m} ; \mathrm{C}, 3$ um. 
TABLE 1. - Spine and seta formula.

\begin{tabular}{lllll}
\hline & Coxa & Basis & Exopod & Endopod \\
\hline Leg 1 & $0-1$ & $1-\mathrm{I}$ & $\mathrm{I}-1 ; \mathrm{I}-1 ; \mathrm{II}, 4$ & $0-1 ; 1, \mathrm{I}, 3$ \\
Leg 2 & $0-1$ & $1-0$ & $\mathrm{I}-1 ; \mathrm{I}-1 ; \mathrm{III}, 4$ & $0-1 ; 1, \mathrm{I}, 3$ \\
Leg 3 & $0-1$ & $1-0$ & $\mathrm{I}-1 ; \mathrm{I}-1 ; \mathrm{III}, 4$ & $0-1 ; 1, \mathrm{I}, 4$ \\
Leg 4 & $0-1$ & $1-0$ & $\mathrm{I}-1 ; \mathrm{I}-1 ; \mathrm{III}, 4$ & $0-1 ; 1, \mathrm{II}, 4$ \\
\hline
\end{tabular}

\section{Praecoxa}

Represented by triangular sclerite at outer proximal angle; each with row of spinules on outer corner of margin. Coxa with spinular row near the proximal outer corner posteriorly. All setae on endopods and exopods slender and plumose, except apical seta on exopod of first leg, which pinnate along outer margin and plumose along inner (Fig. 5A); no modified setae observed. All spines strong and bipinnate. Segments of both rami with spinules near the bases of all spines. Intercoxal sclerite without any surface ornamentation, except on posterior surface of fourth leg. Exp-1 with posterior spinular row near distal margin.

\section{Leg 1 (Fig. 5A)}

Coxa ornamented with distal row of minute spinules on anterior surface, armed with long and plumose seta on inner-distal corner; basis armed with outer plumose seta and spinulose spine on inner margin near base of endopod (arrowed and indicated by a star in Fig. 5A), with two posterior rows of shorter and stronger spinules on anterior surface (one at base of inner seta, other at base of endopod), and one cuticular pore on anterior surface close to outer margin; exopod with row of slender inner spinules on first and second segment, inner seta of exp- 2 better developed than other exopodal setae; endopod armed with one inner seta on first segment, second segment with three inner setae, one apical spine, and one outer seta, ornamented with slender spinules along outer margins of both segments, single terminal pore on anterior surface of second segment; second endopodal segment with small outer notch in outer margin showing ancestral segmentation.

\section{Legs 2-4 (Fig. 5B-D)}

Coxa armed with plumose inner seta, and bearing distal row of spinules and small pore on anterior surface (with complex spinular rows in leg 4 as figured in Figure 5E); basis with naked outer seta (plumose in leg 3), with very small spiniform outgrowth at outer distal corner in leg 3, with few setules along inner margin; inner margin of all exopod segments, outer margin of all endopodal segments and outer margin of exp-2 with few setules (except leg 4), with three outer spines on exp-3; second endopodal segment with outer notch showing ancestral segmentation, and longer than first segment. Enp-1 of leg 2 and leg 4 with posterior spinular row located terminally (Table 1).
Leg 5 (Fig. 3J)

Inserted laterally, relatively small, two-segmented. Proximal segment short, almost rhomboidal in shape, armed with single slender plumose outer basal seta. Exopod small and cylindrical, armed with apical long plumose seta and subapical small inner spine; Leg 6 (Fig. 6B, C) represented by one plumose seta and two short spines dorsolaterally, inner spine fused to plate, outer articulated basally.

\section{DESCRIPTION OF MALE (ALLOTYPE)}

Smaller than female (Figs 1B; 2G)

Body length excluding caudal setae, $470 \mu \mathrm{m}$ (range $=464-$ $588 \mu \mathrm{m}$, mean $=505 \mu \mathrm{m}, n=5$ ); body width, $167 \mu \mathrm{m}$ $($ range $=167-173$, mean $=170 \mu \mathrm{m}, n=5)$. Urosomites without any surface ornamentation (Fig. 7A, B). Genital somite 1.6 times as wide as long in dorsal view. Abdominal somites with finely serrated hyaline fringe dorsally, less serrated ventrally (Figs 7A, B; 8B). Caudal seta I extremely small as in female, and originating below a small spinule (Fig. 8A). Fifth leg similar to that of female but smaller (Fig. 8E). Sixth leg (Fig. 8C, D) armed with one inner and two outer plumose setae.

\section{Antennule (Figs 9A-C; 10A-G)}

Indistinctly 17-segmented. Segments 8-10 partially fused anteroventrally. Sixteenth and seventeenth (apical) segments partly fused on ventral side. Geniculation located between segments 14 and 15 . Armature formula as follows: $8+3 \mathrm{ae}$; 4; 2; 2+ae; 2; 2; 2; 2; $2+1$ ae; $2 ; 2 ; 2 ; 2+1$ ae; $2+1$ modified plate-like element +1 cone-like element +1 ae; $1+2$ modified plate-like elements +1 ae +1 cone like element; $4+1$ ae; $8+1$ ae. Segmental fusion pattern as follows I-V, VI-VII, VIII, IX, X, XI, XII, XIII, XIV, XV, XVI, XVII, XVIII, XIX-XX, XXIXXIII, XXIV-XXV, XXVI-XXVIII. Segment 1 with the slender seta A (arrowed in Fig. 9B); seta G present; aesthetascs linguiform; the seta G present (arrowed in Fig. 9B). Segment 10 (= ancestral segment XV) produced on one side into sheath enclosing segment 11 ventrally; armed with two setae. Segment 12 armed with short naked seta, plus short, strong (but not highly modified) chitinized spine (arrowed in Figs 9B; 10A-C). Segment 14 (= ancestral segments XIX-XX) armed with a minute proximal seta and one distal seta, plus one modified plate-like modified element attached to segment, and one aesthetasc embedded between the segment and the modified element (arrowed in Fig. 10D); main part of modified element lying along surface of segment and ornamented with longitudinal ridges and small central pore (arrowed in Fig. 10D). Segment 15 armed with one normal seta, two plate-like modified elements (as proximal element on segment 14) each ornamented with longitudinal ridges and a central pore (arrowed in Fig. 10E) and one aesthetasc (arrowed in Fig. 10E). Segmental boundary between 16 and 17 (apical segment) unclear and especially difficult to determine ventrally. Apical segment tapering distally; armed with 8 setae (one seta located near the terminal margin of segment 16) and one setiform aesthetasc fused basally to one seta, mostly originating on outer (posterior) surface, six setae biarticulate proximally (Figs 9C; 10F, G). 


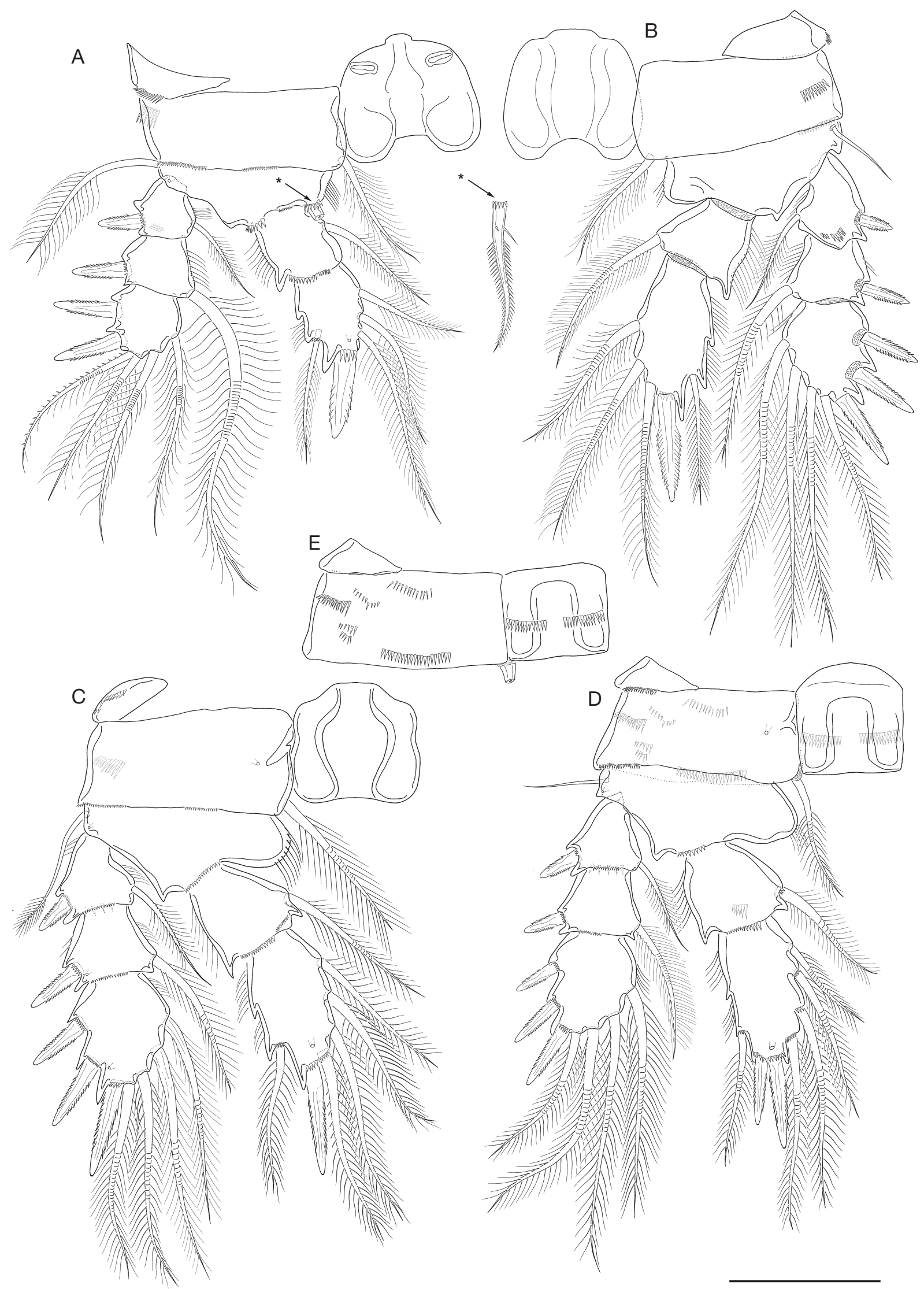

FIG. 5. - Monchenkocyclops mehmetadami n. sp., holotype 9 , swimming legs: A, P1, anterior view, arrow indicating inner basal seta; B, P2, posterior view; C, P3, anterior view; D, P4, anterior view; E, P4, praecoxa, coxa and intercoxal sclerite posterior view. Scale bar: $50 \mu \mathrm{m}$. 


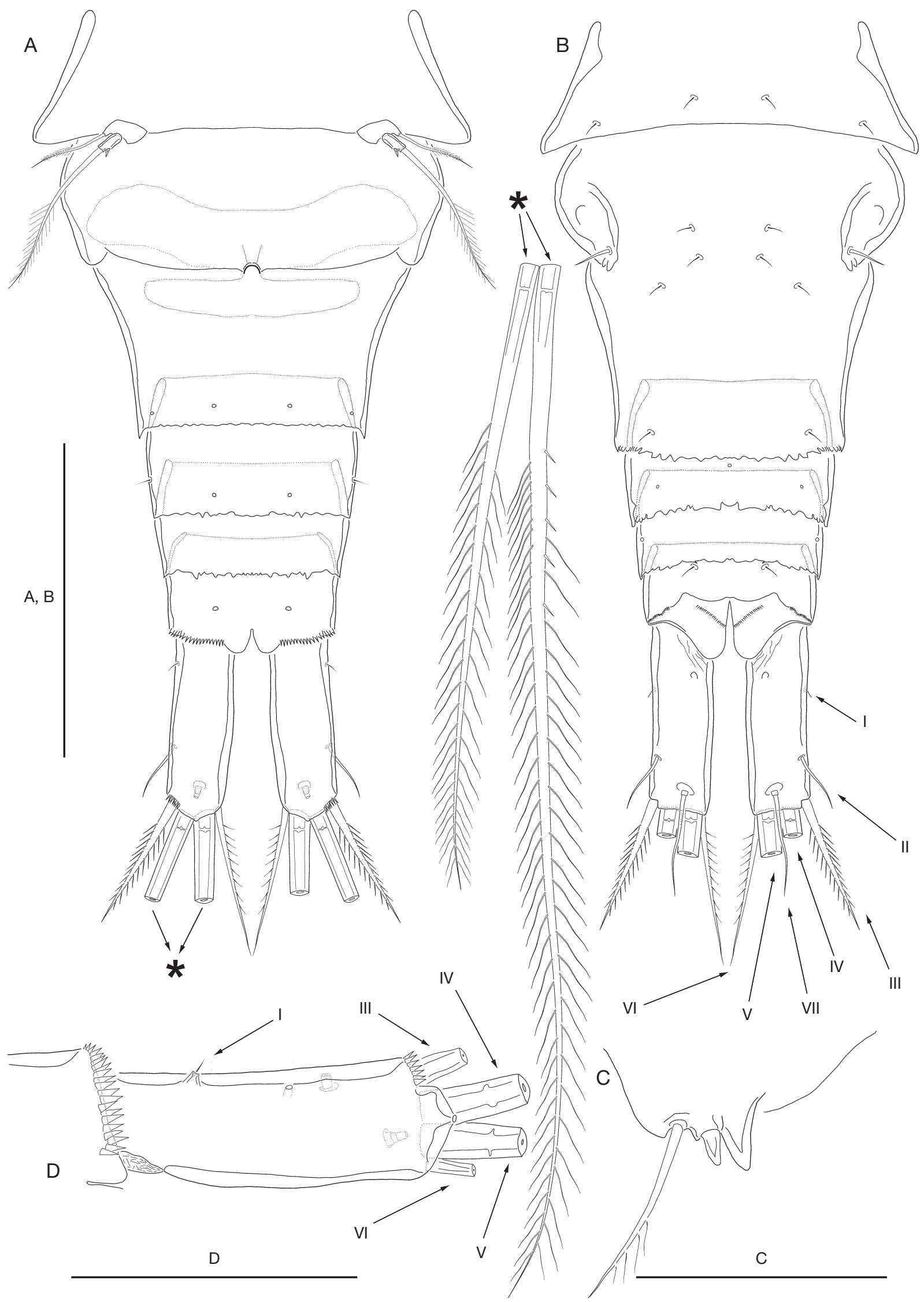

FIG. 6. - Monchenkocyclops mehmetadami n. sp., holotype : : A, urosome, ventral view; B, urosome, dorsal view; C, P6, lateral view; D, furcal ramus, ventral view. Roman numerals indicating terminology proposed by Huys et al. (1996). Symbol: $\star$, indicating insert of seta IV and V. Scale bars: A, B, $100 \mu \mathrm{m} ; \mathrm{C}, 25 \mu \mathrm{m}, \mathrm{D}, 50 \mu \mathrm{m}$. 


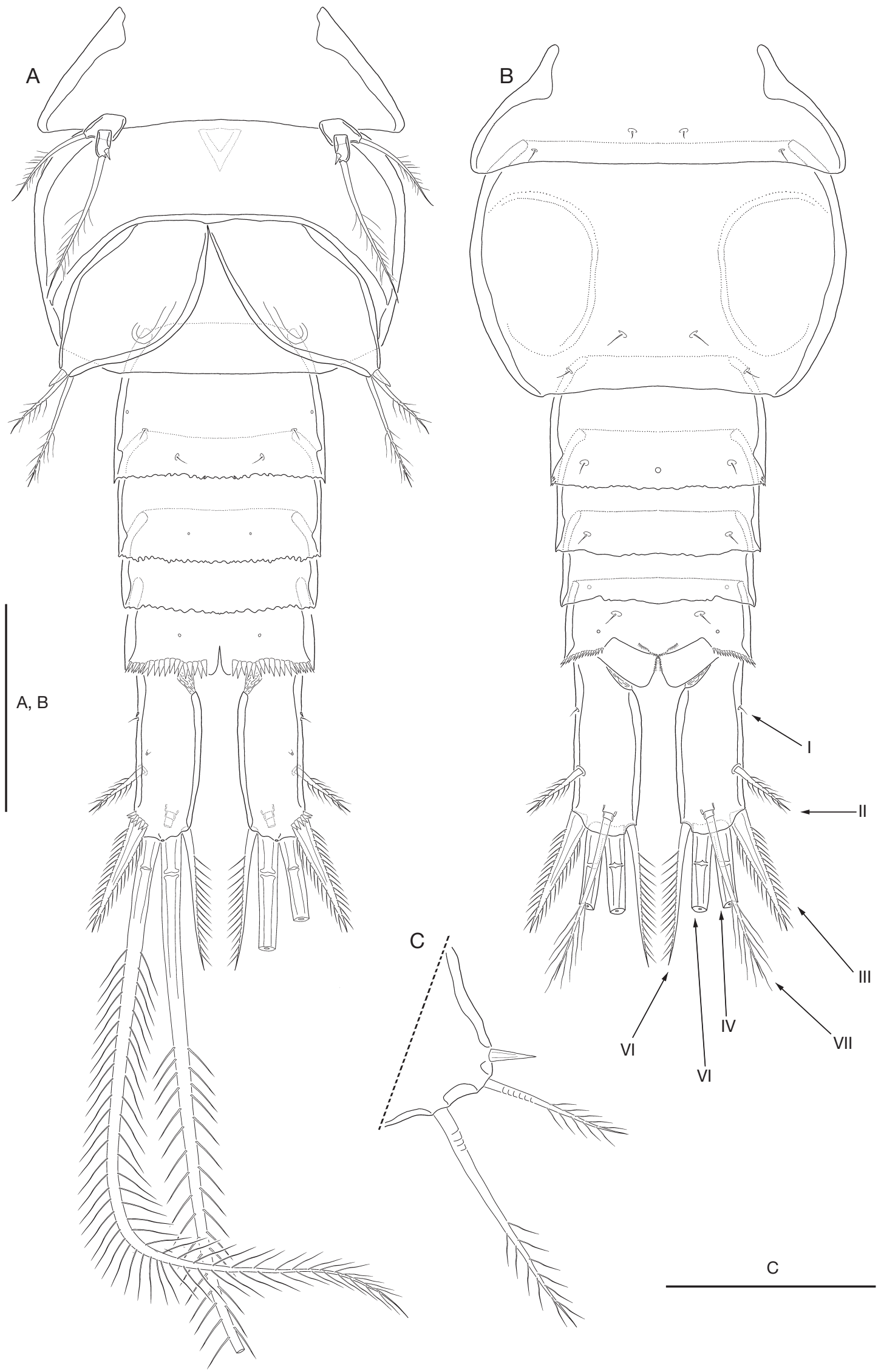

FIG. 7. - Monchenkocyclops mehmetadami n. sp., allotype ơ: A, urosome, ventral view; B, urosome, dorsal view; C, P6, lateral view. Roman numerals indicating terminology proposed by Huys et al. (1996). Scale bars: A, B, $50 \mu \mathrm{m} ; \mathrm{C}, 25 \mu \mathrm{m}$. 

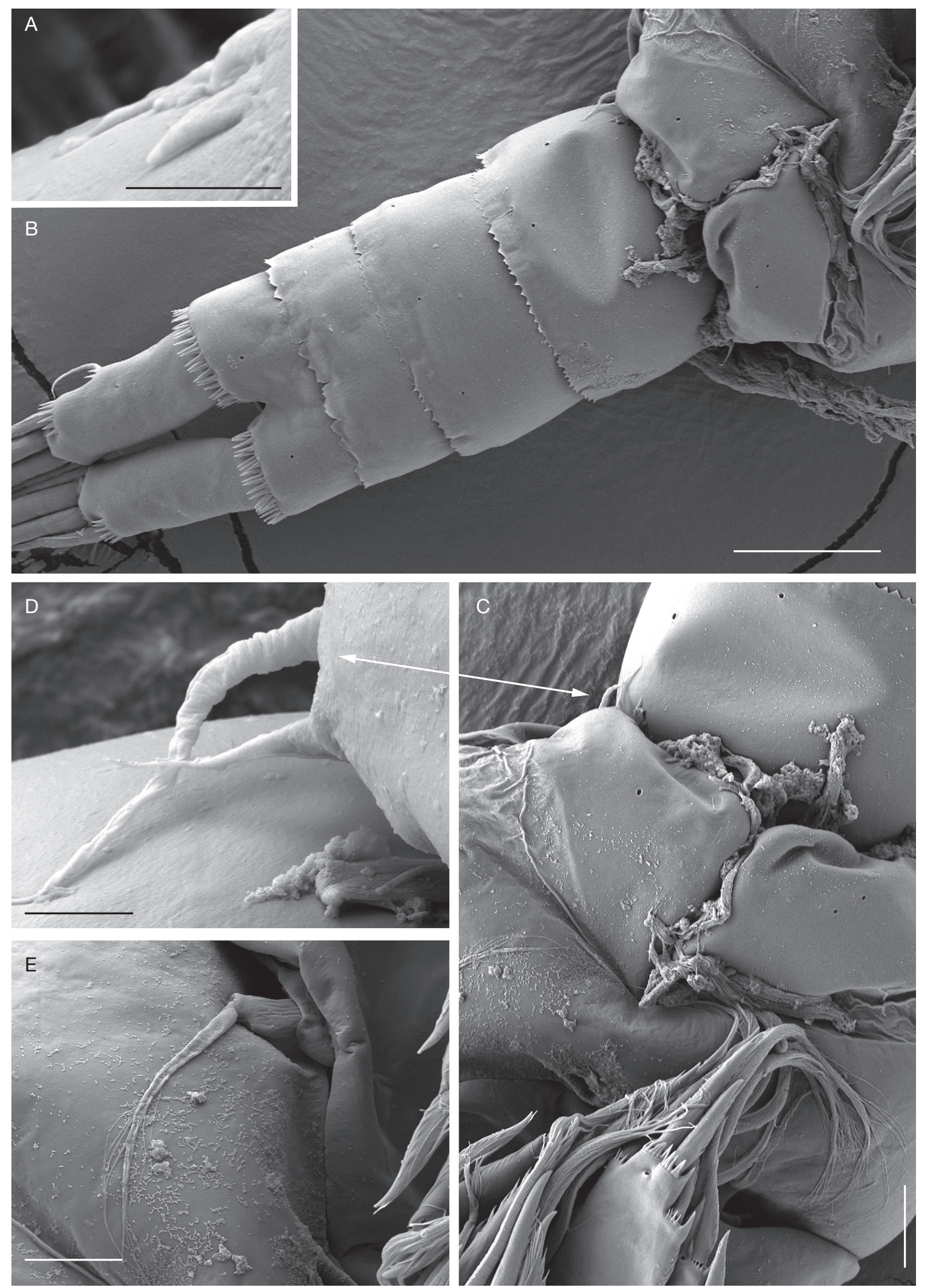

FIG. 8. - Scanning electron micrographs of Monchenkocyclops mehmetadami n. sp., paratype ơ: A, inset of caudal rami, detail of seta I; B, urosome, ventral view; C, plates of P6, arrow indicating setal elements of P6; D, details of P6 showing setal elements; E, P5 ventral view. Scale bars: $A, D ; 1 \mu \mathrm{m}, B, 10 \mu \mathrm{m} ; \mathrm{C}, 5 \mu \mathrm{m} ; \mathrm{D}, 1 \mu \mathrm{m} ; \mathrm{E}, 4 \mu \mathrm{m}$. 


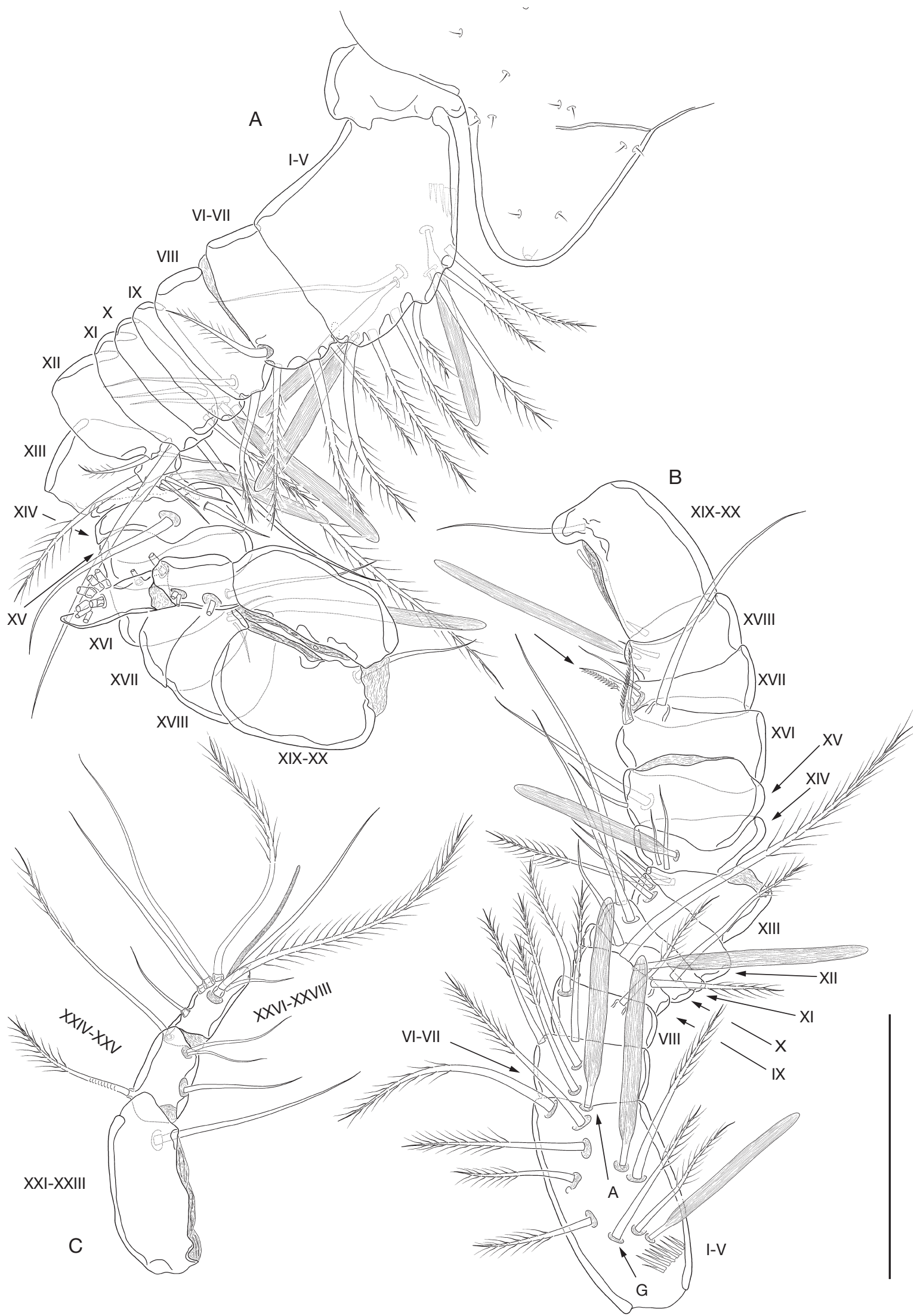

FIG. 9. - Monchenkocyclops mehmetadami n. sp., allotype o': A, antennule, dorsal view; B, antennule, anterior view; C, antennule, distal segments, ventral view. Roman numerals indicating segment homologies as proposed by Huys \& Boxshall (1991). Scale bar: $50 \mu \mathrm{m}$. 

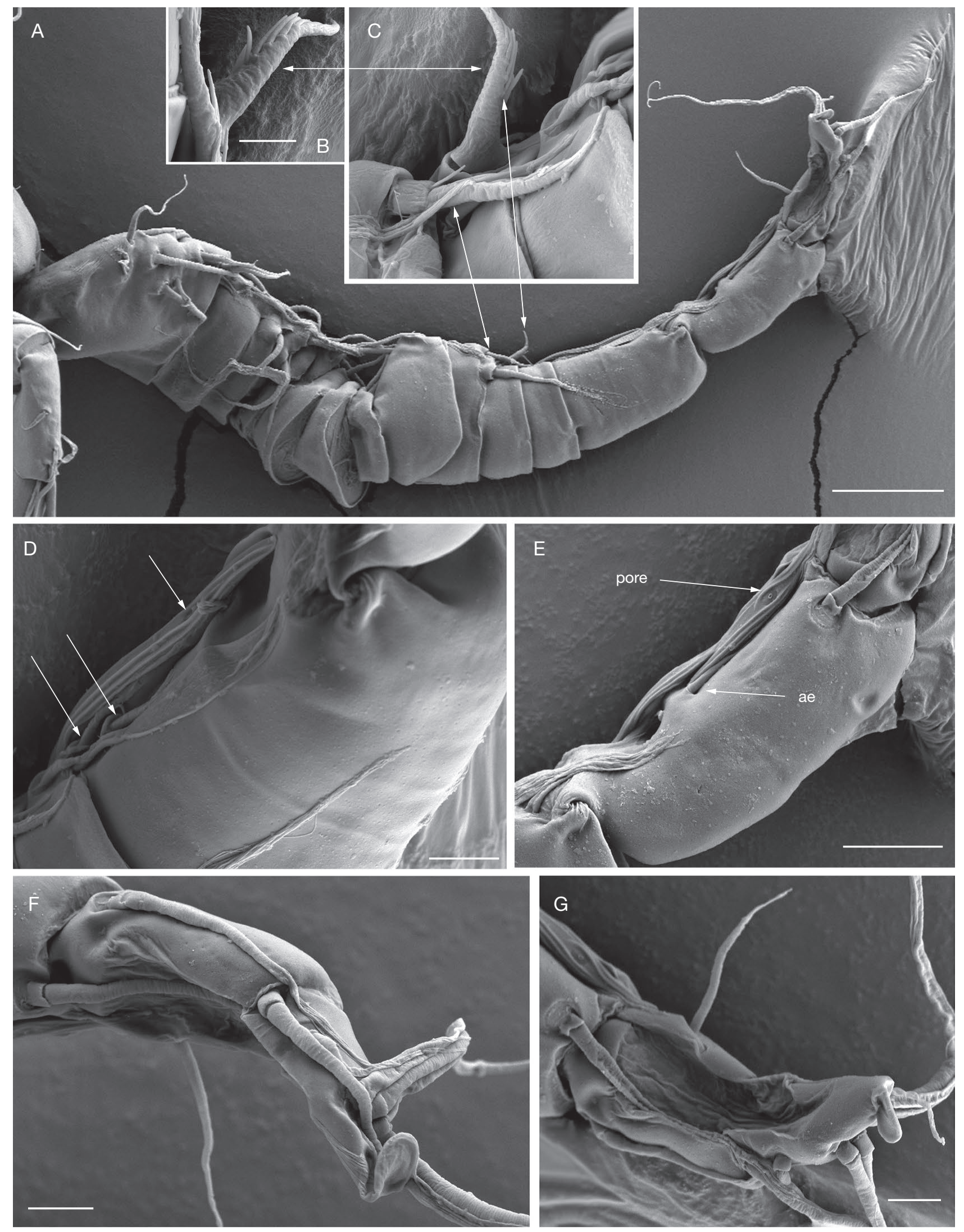

FIG. 10. - Scanning electron micrographs of Monchenkocyclops mehmetadami n. sp., paratype ơ: A, antennule, ventral view; B, C, inset showing detail of modified seta on segment 11 (ancestral segment $(\mathrm{XVI})$ and 12 (ancestral segment XVII), ventral view; D, segment 14 (ancestral segment (XIX-XX), ventral view; E, segment 15 (ancestral segment (XXI-XXIII), ventral view; F, segments 16 and 17, ventral view; G, segment 17, posterior view. Scale bars: A, $10 \mu \mathrm{m} ; \mathrm{B}, \mathrm{C}, 1 \mu \mathrm{m}$; D, F, G, $2 \mu \mathrm{m} ; \mathrm{E}, 4 \mu \mathrm{m}$. 


\section{DISCUSSION}

Monchenkocyclops mehmetadami $\mathrm{n}$. sp. morphologically most resembles the members of the genus Monchenkocyclops. They share the segmentation of the swimming legs, the caudal rami shape and armature, absence of exopod on the antenna and the structure of the P5 (Karanovic et al. 2012). But, the new species can easily be differentiated from the members of Monchenkocyclops by having: three setae on the inner margins of P1-enp2 and P2-enp2; four setae on the inner margin of P3-enp2 and P4- enp2. The new species can also be distinguished from the other species of the genus by having much longer and plumose inner basal seta of P1 basis and by the spinular pattern on the coxobasis of antenna. The new species is also closely related to the kieferi-group (Pandourski 1997; Iepure \& Defaye 2008) of Acanthocyclops (A. biarticulatus Monchenko, 1972 was transferred to the genus Monchenkocyclops by Karanovic et al. 2012). But, two segmented endopod of P2-P4 easily differentiate the new species from the members of kieferi-group.

Whether the erection of the genus Monchenkocyclops has been justified or not due to its paraphyletic status is beyond the scope of this study. But, Karanovic et al. (2012) was aware of the paraphyletic status of the genus Monchenkocyclops and stated that they had no philosophical problems with paraphyletic taxa. "They see them as necessary in bridging the gap between the Darwinian concept of speciation, Henningian concept of phylogeny based on character analyses, and Linnean system of nomenclature". Application of modern phylogenetic techniques based on especially molecular data on a wider group of Cyclopidae species would greatly help to test monophyletic status of Monchenkocyclops and other closely related genera.

On the other hand, unfortunately, species descriptions even in recent published papers still suffer from inadequate morphological details. Several studies using morphological data to separate closely related freshwater cyclopoid species have proved that morphology can in reality provide remarkable results (Van de Velde 1984; Karaytuğ \& Boxshall 1998; Hołyńska \& Dimante-Deimantovica 2016; Karanovic et al. 2016). The morphological information has yet not sufficiently been revealed or evaluated can also provide important characters that can be used in phylogenetic studies (Hołyńska \& Dimante-Deimantovica 2016). For instance, for each taxon described, the number of antennulary segments is usually mentioned, but no reference is made to the homology of those segments. Such a procedure renders the adequate use of segmental data in systematic studies impossible. Although, such segmental fusions on the antennules may not always be useful in species identification, they can provide reliable additional characters that can be used in reconstructions of the phylogenetic relationships in Cyclopidae (Huys \& Boxshall 1991; Karaytug \& Boxshall 1996, 1998; Boxshall \& Huys 1998; Schutze et al. 2000). For example, twelve is the largest number of segments known for the antennules of adult females in the genus Monchenkocyclops which is found in M. biwensis
(Ishida, 2005). Common setation pattern containing number of elements which act as reference points along the limb, in concert with other setation features can easily be used as markers and facilitate the unequivocal identification of homologous segments (Karaytug \& Boxshall 1996, 1998; Schutze et al. 2000). Comparative studies indicate that the third and fourth segments of Monchenkocyclops biwensis are represented by a single compound segment in other Monchenkocyclops species that have 11-segmented antennules. A total of eight elements is retained on the compound third segment in these species and this is the same as the total number of setae on the third and fourth antennulary segments in Monchenkocyclops biwensis. The compound third segment is derived by failure of separation during development. Huys \& Boxshall (1991) postulated that segmental fusion can be considered as a derived state. So, the fusion of third (ancestral segment VIII) and fourth (ancestral segments IX-XI) segments is a synapomorphic character for Monchenkocyclops species having 11-segmented antennules.

The setation of the mouth parts in Cyclopidae is usually very conservative. On the other hand, it is interesting to note that a short seta/spine proximally to the proximalmost robust seta on the praecoxal arthrite of the maxillule could not be observed in the new species and is not present in other Monchenkocyclops species. The loss of this seta might be an important apomorphy of Monchenkocyclops (or a larger group of the Acanthocyclops). But, the presence or absence of this seta should be used with caution in the taxonomy of Cyclopidae since the examination of such elements on the maxillule may be extremely difficult and can easily be overlooked.

\section{Acknowledgements}

We wish to thank the reviewer Dr Maria Hołyńska and the other anonymous reviewers for their useful comments.

\section{REFERENCES}

Boxshall G. A. \& Halsey S. H. 2004. - An Introduction to Copepod Diversity. The Ray Society, London, 966 p.

BOXSHALL G. A. \& HUYS R. 1998. - The ontogeny and phylogeny of copepod antennules. Philosophical Transactions of the Royal Society B 353: 765-786.

Delamare Deboutteville C. 1953. - Recherches sur l'écologie et la répartition du mystacocaride Derocheilocaris remanei Delamare et Chappuis, en Méditerranée. Vie Milieu 4: 321-380.

HoŁYŃSKA M. \& DimanTE-DeimantoviCA I. 2016. - Redescription and taxonomic notes on Cyclops bohater Koźmiński, 1933 and Cyclops lacustris G. O. Sars, 1863 (Arthropoda, Crustacea), with an identification key to the Cyclops species of Fenno-Scandinavia. European Journal of Taxonomy 212: 1-31. https://doi. org/10.5852/ejt.2016.212

Huys R. \& Boxshall G. A. 1991. - Copepod Evolution. The Ray Society, London, 468 p.

Huys R., GeE J. M., Moore C. G. \& Hamond R. 1996. — Synopses of the British Fauna (New Series): Marine and brackish water harpacticoid copepods, Part 1. Synopses of the British Fauna, New Series 51: $352 \mathrm{p}$. 
IEPURE S. \& DeFAYE D. 2008. - The Acanthocyclops kieferi complex (Copepoda, Cyclopoida) from southeastern Europe, with description of a new species. Crustaceana 81 (5): 611-630.

IsHIDA T. 2005. - Diacyclops biwensis, a new cyclopoid copepod (Crustacea) from Lake Biwa, Japan. Biogeography 7: 51-54.

Karanovic T., Yoo H. \& LeE W. 2012. - A new cyclopoid copepod from Korean subterranean waters reveals an interesting connection with the Central Asian fauna (Crustacea: Copepoda: Cyclopoida). Journal of Species Research 1: 156-174.

Karanovic T., DJurakic M. \& Eberhard S. 2016. - Cryptic species or inadequate taxonomy? implementation of $2 \mathrm{~d}$ geometric morphometrics based on integumental organs as landmarks for delimitation and description of copepod taxa. Systematic Biology 65: 304-327. https://doi.org/10.1093/sysbio/syv088

KaraYTUG S. \& BoXshall G. A. 1996. - The life cycle of Paracyclops fimbriatus (Fischer, 1853) (Copepoda, Cyclopoida). Bulletin of the Natural History Museum London (Zoology) 62: 41-70.

Karaytug S. \& Boxshall G. A. 1998. - Female antennules of Paracyclops (Copepoda, Cyclopidae): their significance in systematics. Journal of Marine Systems 15: 397-400.
Karaytug S. \& Boxshall G. A. 1999. - Antennules of male Paracyclops (Copepoda): functional significance and their importance in systematics. Journal of Crustacean Biology 19: 86-92.

KAYMAK (BOZKURT) N. \& KARAYTUĞ S. 2014 - Systematics of the genus Heterolaophonte (Crustacea, Copepoda, Harpacticoida), with redescription of $H$. uncinata and $H$. Curvata. Zootaxa 3780 (3): 503-533. https://doi.org/10.11646/zootaxa.3780.3.4

PANDOURSKI I. S. 1997. - Composition, origine et formation de la faune cyclopidienne stygobioe de Bulgarie et définition du groupe d'espèces "kieferi" du genre Acanthocyclops (Crustacea, Copepoda, Cyclopoida). Bolletino del Museo Regionale di Scienze Naturali Torino 15: 279-297.

Schutze M. L. M., Rocha C. E. F. \& Boxshall G. A. 2000. Antennulary development during the copepodid phase in the family Cyclopidae (Copepoda, Cyclopoida). Zoosystema 22: 749-806.

VAN DE VeLDE I. 1984. — Introduction of new diagnostic characters in Mesocyclops, with African species as an example, in KIRSCH K, editor. Studies on Copepoda II. Proceedings of the First International Conference on Copepoda; 1981 Aug 24-28, Amsterdam, Crustaceana, $435 \mathrm{p}$. 